Dept. of Biotechnology,

Animal Health Research Institute, Dokki.

\title{
MOLECULAR DETECTION OF LISTERIA MONOCYTOGENES PATHOGENIC GENES AS FOOD POISONING MICRO-ORGANISM ISOLATED FROM READY- TO- EAT MEALS IN PORT-SAID CITY MARKETS
}

(With 3 Tables and 5 Figures)

By

\section{HANAA A. AHMED; AMAL A. MEGAHED* and} GIHAN M.O. MOHAMMED*

* Dept. of Bacteriology, Animal Health Research Institute, Port-Said Branch. (Received at 12/12/2011)

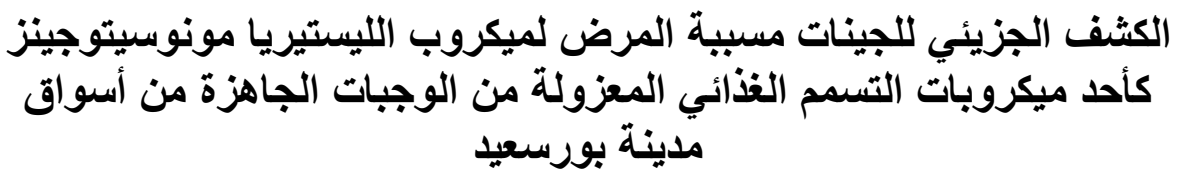

هناء عبل القادر ، أمل أحمد مجاهد ، جيهان محد عمر محمد

تم تجميع 1 ـ عينة من الوجبات السريعة (10 عينة لكل من الكفتة، الكبدة، اللانشون،

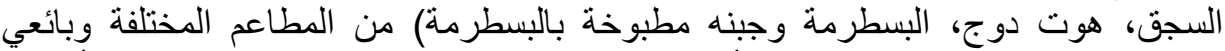

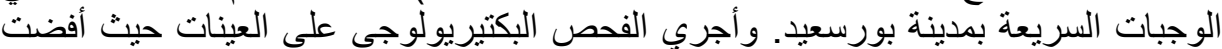

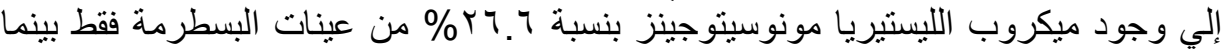

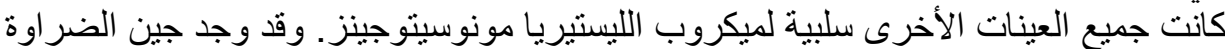

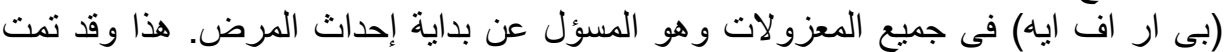

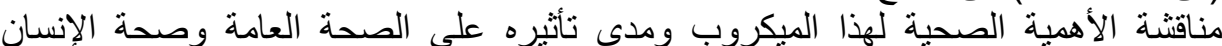
وكذلك الثروط الواجب نوافر ها وإتباعها للمحافظة على لئل سلامة الوجبات السرة السريعة.

\section{SUMMERY}

Listeria monocytogenes is a major safety concern for ready- to- eat (RTE) meals, which are frequently contaminated with this pathogen. So a total of 105 random samples represented by 7 kinds of ready -to-eat meals (kofta, fried liver (kibda), luncheon, sausage, hotdog, cooked cheese with basturma and basturma) were collected from different supermarkets and street venders in Port-Said City. L. monocytogenes 
was isolated from basturma only in 4 samples $(26.6 \%)$. On other hand $L$. monocytogenes could not be isolated from any of the other examined samples. Polymerase chain reaction is a powerful technique for detection of pathogens in foods. It is a rapid procedure with both sensitivity and specificity for quick detection and identification of specific pathogenic bacteria from different sources. Listeria monocytogenes detection methods based on PCR amplification of the prfA and hly genes sequences have been reported. The virulence gene $\operatorname{prf} A$ was found in all isolates which is responsible for the initiation of pathogenesis so its target is to detect pathogenic L. monocytogenes. The public health hazard of this microorganism as well as recommended measures to improve quality status of ready- to- eat (RTE) meals was discussed.

Key words: Listeria monocytogenes detection, ready-to- eat meals, Foodborne disease, PCR, Public health.

\section{INTRODUCTION}

In recent years, there was an increased trend for RTE meals to be consumed both at home and restaurants. RTE meals such as kofta, fried liver (kibda), luncheon, sausage, hot dog, cooked cheese with basturma and basturma have become more popular RTE meals in Middle East countries. They considered the most common RTE sold by street vendors and fast food restaurants (Cressey and Lake, 2005; Vorst et al., 2006; Acciari et al., 2011).

Because of the changing life style in Egypt, people consume a variety of fast foods on a daily basis. Traditional meals- containing fast foods such as kofta, fried liver (kibda) sandwiches became more popular (Hamedy et al., 2007).

Food-borne infections are important public health concern worldwide. According to reports of the World Health Organization and the Center for Disease and Prevention, every year a large number of peoples are affected by food borne diseases due to consumption of contaminated beef (Busani et al., 2005; Cressey and Lake, 2007).

Meat constitutes the most important items of human food because of its palatability and high nutritional value, at the same times, meat is prone to contamination from the hands and clothes of staff, knives and other equipments occurred post production or recontamination during further handling (Gill et al., 2001; El-prince and Sayed, 2004). 
Listeriosis is a foodborne bacterial disease caused by L. monocytogenes, that is widely spread throughout the environment. It had been isolated from soil, water, silage, and many other environmental sources. The organism can grow in $\mathrm{PH}$ range of $4.4^{\circ} \mathrm{C}-9.4^{\circ} \mathrm{C}$. resists high salt levels, nitrite, acid and relatively resistant to drying, but easily destroyed by heating and it can grow between $0^{\circ} \mathrm{C}-45^{\circ} \mathrm{C}$. (Janny, 2007; Sue et al., 2009). L. monocytogenes was found in at least 37 species of mammals, both domestic and wild, as well as up to $10 \%$ of human may be intestinal carriers. It had been detected in 17 species of birds, some species of fish and shellfish, and is especially pathogenic to high risk populations, such as newborn, pregnant women, elderly, and immunocompromised individuals (Mugampoza et al., 2011).

Although listeriosis is relatively uncommon, it is a potentially fatal disease. It frequently result in abortions in pregnant women. Even though the symptoms may be relatively mild in the mother, the illness may be transferred to the fetus causing serious illness or fetal death. Some symptoms of L. monocytogenes may include meningitis, encephalitis, septicemia, spontaneous abortion, still birth, and influenzalike symptoms (William and Catherine, 2001; Sutherland et al., 2003; Azevedo et al., 2005; Sue et al., 2009).

Detection of L. monocytogenes by molecular methods is very specific and can be as fast as the immunological assays (Janzten et al., 2006). A number of PCR assays had been described for its detection in foods (Levin, 2003). PCR methods had superior sensitivity when compared to standard nucleic acid probes or immunoassays. However, complex sample preparation methods and the use of gel electrophoresis endpoint detection have hampered the transition of these methods from research to routine use in food microbiology laboratories. Nevertheless, factors influencing the performance of conventional PCR in foods continue to be investigated (Aznar and Alarcón, 2003) and standardized (D’Agostino et al., 2004).

Sequence comparison of individual genes in the $\operatorname{prf} A$ virulence gene cluster $(p V G C)$, a central virulence gene cluster, from different Listeria species indicated that priming sites within the genes appeared to be specific for Listeria monocytogenes exclusively. Therefore, the pVGC was targeted for polymerase chain reaction (PCR) assays to detect and specifically identify L. monocytogenes. Each gene of the $p V G C$ was specifically amplified in L. monocytogenes but not in other Listeria species (Jung et al., 2009). 
This study was planned to investigate the presence of L. monocytogenes among some selected ready- to- eat (RTE) meals using the classical methods of isolation in comparison with molecular tools. It also aimed to detect one of the virulence genes cluster $(p V G C)$ responsible for initiation of pathogenesis ( $\operatorname{rrf} A$ gene).

\section{MATERIALS and METHODS}

\section{A - Collection of Samples:}

A total of 105 random samples of RTE meals included fried liver (kibda), kofta, sausage, hotdog, luncheon, cooked cheese with basturma and basturma from different supermarkets and street vender in Port-Said City for detection of L. monocytogenes.

\section{B - Isolation:}

Twenty-five grams of each RTE meals samples were homogenized in a stomacher for $2 \mathrm{~min}$ in $225 \mathrm{ml}$ of Listeria enrichment broth (Difco), and incubated at $30^{\circ} \mathrm{C}$ for $48 \mathrm{hr}$. the samples were divided into 2 portions, one for molecular identification and the other to continue the isolation. After incubation one loopful was subcultured on Listeria Oxford medium base. The plates were incubated at $35^{\circ} \mathrm{C}$ for $24-48 \mathrm{~h}$.

\section{C - Identification:}

Five typical colonies were transferred from Listeria Oxford medium base to Trypticase soy agar with yeast extract for purification. Purified isolates were identified by the Gram- stain, Catalase test, motility test, biochemical tests and Christie- Atkins, Munch- Petersen; test of haemolysis (CAMP Test). Further confirmation of L. monocytogenes the isolates were inoculated in to $10 \%$ aqueous stock solution of Manitol, L. Rhamnose and D. Xylose (FDA, 2003).

\section{D - Polymerase chain reaction (PCR)}

DNA Extraction: Boiling method (Bansal, 1996). Bacterial pellets were

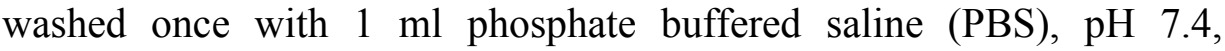
resuspended in a same volume of cold water and incubated in a boiling water bath for $10 \mathrm{~min}$. The clear supernatants obtained after a $5 \mathrm{~min}$ centrifugation at $12000 \mathrm{~g}$ were used for PCR reaction.

Oligonucleotide Primers: in this study 2 sets of primers were used, hyl gene specific for conformation of $L$. monocytogenes and not any other type of Listeria and prfA gene the initiator gene for pathogenesis. The sequence, cycling conditions and amplicone size were described in table 
(1). The PCR products were visualized on 1.3\% agarose gel in 1x TBE using GeneRuler 100 bp plus DNA Ladder (Fermentas Cat. No. \#SM0323).

Table 1: Shows the sequence, cycling conditions and amplicone size of the used genes:

\begin{tabular}{|c|c|c|c|c|}
\hline Gene & Sequence $5 \backslash-3^{\backslash}$ & Cycling condition & $\begin{array}{l}\text { Produ } \\
\text { ct size }\end{array}$ & Reference \\
\hline hyl & $\begin{array}{l}\text { LM1 CCT-AAG -ACG-CCA- } \\
\text { AT C-GAA } \\
\text { LM2 CCT-AAG -ACG-CCA- } \\
\text { AT C-GAA }\end{array}$ & 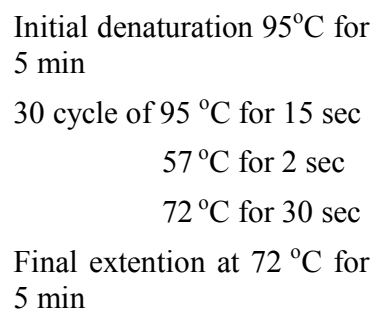 & $702 \mathrm{bp}$ & $\begin{array}{l}\text { Mengaud et al } \\
(1988)\end{array}$ \\
\hline $\operatorname{prfA}$ & $\begin{array}{l}\text { prfA-A CTG-TTG-GAG - } \\
\text { CTC-TTC-TTG- } \\
\quad \text { GTG-AAG -CAA- } \\
\text { TCG } \\
\text { prfA-B AG C-AAC-CTC- } \\
\text { GGT-ACC- ATA } \\
\quad \text {-TA C- TAA -CTC }\end{array}$ & $\begin{array}{l}\text { Initial denaturation } 95^{\circ} \mathrm{C} \text { for } \\
5 \mathrm{~min} \\
30 \mathrm{cycle} \text { of } 95^{\circ} \mathrm{C} \text { for } 15 \mathrm{sec} \\
60^{\circ} \mathrm{C} \text { for } 30 \mathrm{sec} \\
72^{\circ} \mathrm{C} \text { for } 90 \mathrm{sec} \\
\text { Final extention at } 72{ }^{\circ} \mathrm{C} \text { for } \\
5 \text { min }\end{array}$ & $\begin{array}{c}1060 \\
\mathrm{bp}\end{array}$ & $\begin{array}{l}\text { Wernars et al } \\
(1992)\end{array}$ \\
\hline
\end{tabular}

\section{RESULTS}

In the present study, all types of RTE food examined (105 samples listed in Table 2 and Fig. 1) were negative to the presence of Listeria except that of Basturma, four samples out of the examined fifteen were positive by isolation with an incidence rate of $26.6 \%$ and overall recovery rate of $3.8 \%$. All Listeria spp. hydrolyze esculin and the inclusion of esculin and ferric iron in enrichment or plating media results in the formation of an intense black color (Fraser and Sperber, 1988). This is due to the complexation of the ferric iron with 6, 7dihidroxycoumarin, the product of esculin cleavage by $\beta$-D-glycosidase, resulting in a black precipitate.

Table 2: Incidence of L. monocytogenes in the examined samples of RTE meals.

\begin{tabular}{|c|c|c|}
\hline Types of samples & No. of samples & Positive samples of \\
\hline
\end{tabular}




\begin{tabular}{|l|c|c|c|}
\hline \multirow{2}{*}{} & \multirow{2}{*}{ examined } & \multicolumn{2}{|c|}{ L. monocytogenes } \\
\cline { 3 - 4 } & & No & $\%$ \\
\hline fried liver( kibda) & 15 & 0 & 0 \\
\hline Kofta & 15 & 0 & 0 \\
\hline Sausage & 15 & 0 & 0 \\
\hline Hotdog & 15 & 0 & 0 \\
\hline Luncheon & 15 & 0 & 0 \\
\hline cooked cheese with basturma & 15 & 0 & 0 \\
\hline basturma & 15 & 4 & 26.6 \\
\hline Total & 105 & 4 & 3.8 \\
\hline
\end{tabular}

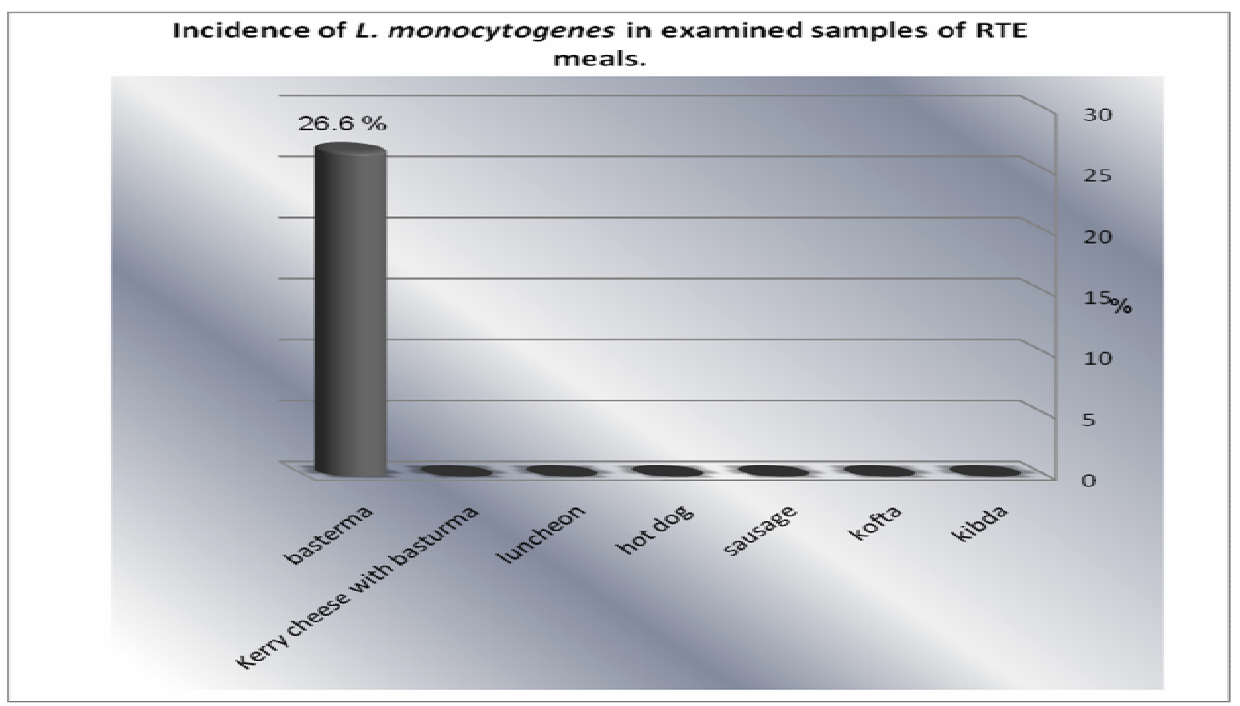

Fig. 1: Incidence of L. monocytogenes in the examined samples of RTE meals.

These isolates were subjected to hemolysis, Christie- Atkins, Munch- Petersen; test of haemolysis (CAMP Test) and acid production tests for differentiation of listeria species as listed in Table 3 and Fig 2. An "arrowhead" hemolysis is seen between growth of Listeria monocytogenes and Group B Staph aureus. This is because of alpha toxin produced by Staph aureus interacts with Christie- Atkins, MunchPetersen; test of haemolysis (CAMP Test) factor and produce synergistic hemolysis. 


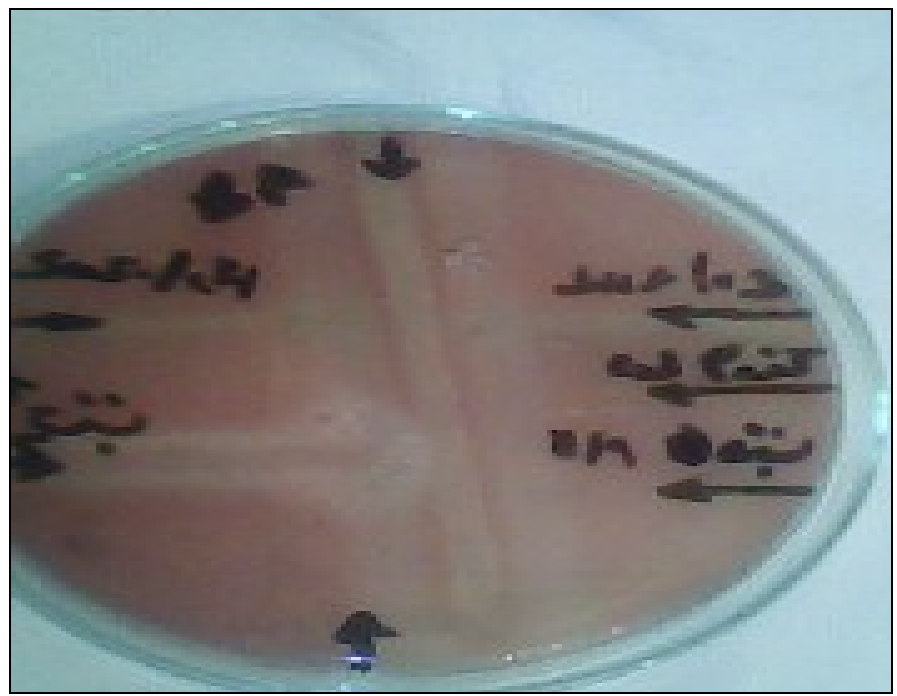

Fig. 2: Listeria monocytogenes on blood agar Christie- Atkins, MunchPetersen; test of haemolysis (CAMP Test) showing the characteristic arrowhead hemolysis between basturma isolates only and Staph aureus.

Table 3: Biochemical differentiation of Listeria species in the examined isolates:

\begin{tabular}{|c|c|c|c|c|c|c|c|c|c|}
\hline \multirow{3}{*}{ Listeria spp. } & \multirow{2}{*}{\multicolumn{2}{|c|}{ Haemolysis }} & \multirow{2}{*}{\multicolumn{2}{|c|}{ CAMP }} & \multicolumn{5}{|c|}{ Acid production from } \\
\hline & & & & & \multicolumn{2}{|c|}{ D-Xylose } & \multicolumn{2}{|c|}{ L-Rhamnose } & Mannito \\
\hline & $\mathrm{C}$ & $\mathrm{T}$ & $\mathrm{C}$ & $\mathrm{T}$ & $\mathrm{C}$ & $\mathrm{T}$ & $\mathrm{C}$ & $\mathrm{T}$ & $\mathrm{C}$ \\
\hline L. monocytogenes & + & +4 & + & +4 & + & +4 & - & - & V \\
\hline L. seeligeri & + & - & $+/-$ & - & - & - & - & - & - \\
\hline L. ivanovii & ++ & - & - & - & + & - & - & - & - \\
\hline L. innocua & - & - & - & - & - & - & $\mathrm{V}$ & - & V \\
\hline L. welshimeri & - & - & - & - & - & - & - & - & + \\
\hline L. grayi & - & - & - & - & + & - & + & - & V \\
\hline
\end{tabular}

+:positive, +/-: weakly positive, -: negative, CAMP: Christie- Atkins, Munch- Petersen; test of haemolysis, $\mathrm{V}$ : variable $\mathrm{C}=$ control, $\mathrm{T}=$ tested isolates 
All samples were subjected to PCR after primary enrichment, The PCR results didn't give any results after first PCR run from initial culture (Fig. 3) compared to L. monocytogenes reference strain; by rePCR only basturma gave a characteristic band at $702 \mathrm{bp}$ to hyl gene specific for L. monocytogenes (Fig. 4).

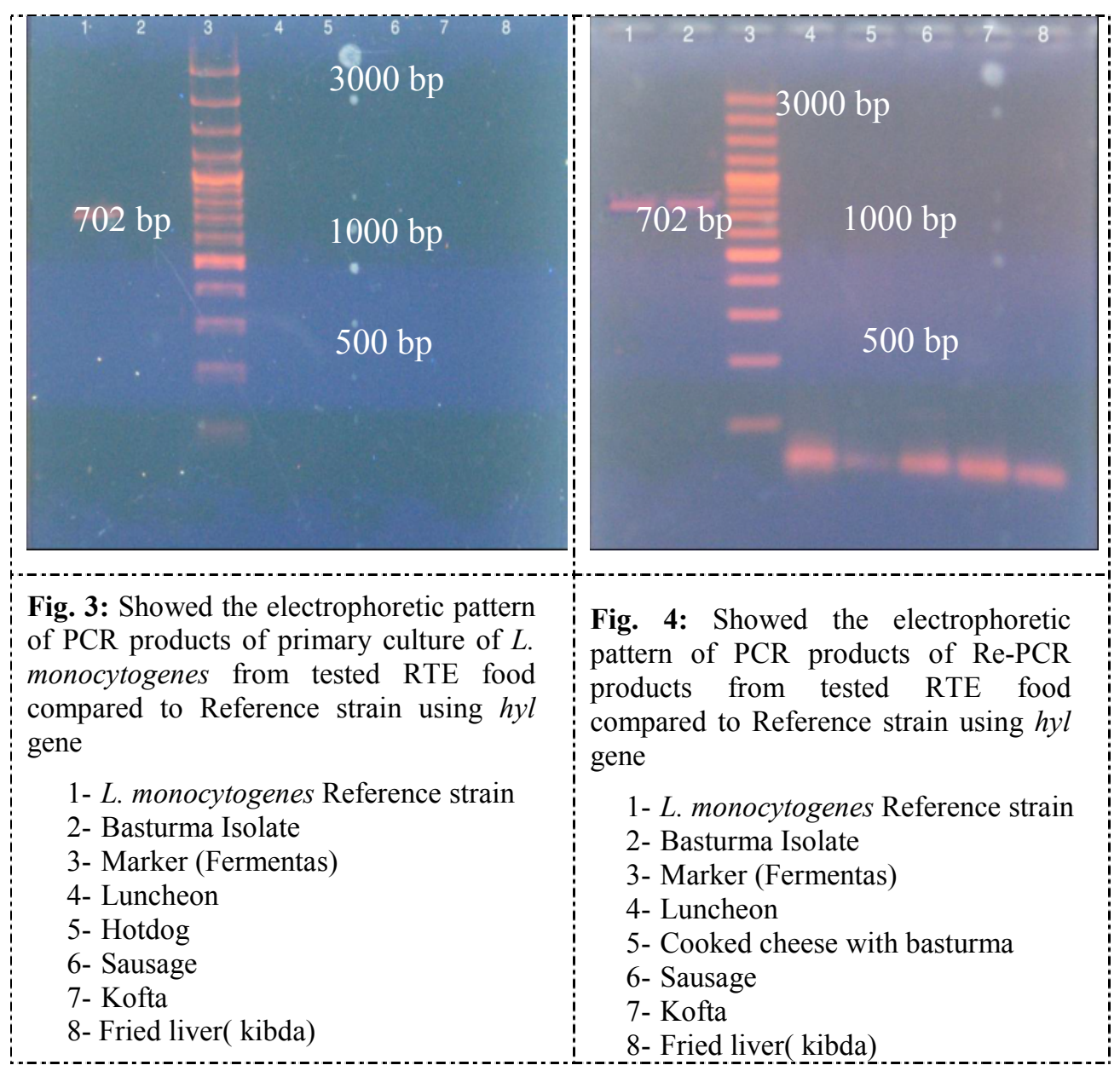

The positive PCR samples for hyl gene were examined for the presence of prfA gene and gave the characteristic band at $1060 \mathrm{bp}$ compared to reference strain (Fig 5) also at the $2^{\text {nd }}$ round PCR (RePCR). 
Fig. 5: Showed the electrophoretic pattern of PCR products from tested RTE food compared to Reference strain using prfA gene

1 - Luncheon

2 - Cooked cheese with basturma

3 - Marker (Fermentas)

4 - Sausage

5 - Kofta

6 - Basturma Isolate

7- L. monocytogenes Reference strain

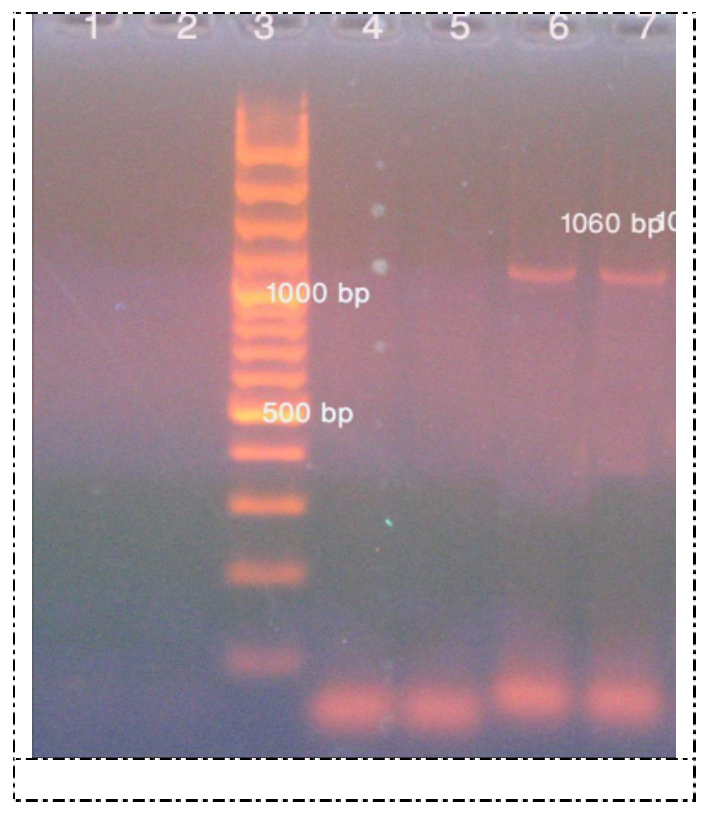

\section{DISCUSSION}

The microbiological safety of food products is of extreme importance to industry, public health officials, regulatory agencies and the public little information is available regarding the occurrence of $L$. monocytogenes in meat, meat product and soft cheese in retail market in Port-Said City. This survey provided a clear picture for the prevalence of L. monocytogenes in RTE meals offered to consumers. L. monocytogenes was isolated from 4 basturma samples with a percentage of $(26.6 \%)$ in Table 2 and figure 3 . In this concern, isolation of $L$. monocytogenes in final products of basturma were have been reported by Steven et al. (2006).

An additional microbiological hazard of potential concern in basturma is Listeria monocytogenes. Basturma is sold as a raw product and some people may consume basturma as it is, while cooking by the consumer is important for preventing food borne illness due to listeriosis associated with this product. L. monocytogenes growth on the finishing product is unlikely because of its reduced water activity (Aw) Guidance from USDA states that, decreasing a products water activity to $<0.92$ and $\mathrm{PH}<4.39$ will prevent $L$. monocytogenes growth (USDA, 2004). The American Meat Institute Foundation (2005) stated that unless the finishing basturma (contained L. monocytogenes at levels greater than 4 $\log$ CFU, or supported growth to such a level), cooking procedures 
should dramatically decrease the risk of basturma -linked Listeriosis. In general, the organism has been found in raw milk, soft cheese, fresh and frozen meat and vegetable products (Hege et al., 2000)

The ability of food borne micro-organisms as L. monocytogenes to become disseminated from naturally contaminated foods to various hand and food contact surface is well know. The results achieved from Tables 2 and 3 revealed that, L. monocytogenes could not be detected in fried liver (kibda), kofta, Luncheon, cooked cheese with basturma, sausage or hot dog samples. The incidence of L.monocytogenes in luncheon meat was Lower than that obtained by Gombas et al. (2003) who found it in $0.89 \%$ of luncheon meat. In contrast, L. monocytogenes could not be isolated from meat samples (Elgazzar and Sallam, 1997; Mohamed; Ali, 1999; Saad et al., 2001). This wide variation may be explained in terms of geographic location, isolation methods and kinds of media employed (Akpolat et al., 2004). Cross-contamination, which can occur within environment of food-processing equipment, is considered to be a possible source of Listeria contamination in processed meat such as luncheon. L. monocytogenes is able to attach to and survive on various working contact surfaces (Borucki et al., 2003). One reason may be its ability to form biofilms (Wong, 1998). Furthermore, during further transformation processes of raw meat into meat products L.monocytogenes can be introduced, where the amount depends on the extent of cross-contamination, personal and general hygienic measures and the process parameters (Glass and Doyle, 1989). In addition, minced/chopped meat products as luncheon, by their nature, undergo extensive processing and handling during their production. This leads to greater opportunities for L. monocytogenes contamination (Tompkin et al., 1992 and Uyttendaele, 1997). The difference occurring, either increase or decrease in the incidence of other literatures than that obtained results, this attributed to the nature processing load to RTE meals, also due to the level of contamination of other additives, which added to the RTE meals and difference in country and type of sample analysis.

The mortality rate of listeriosis is very high, approximately $30 \%$ (Griffiths, 1989), and for this reason the Food and Drug Administration maintains a policy of zero-tolerance for L. monocytogenes (Anon, 2003). With this concern, the ability to detect this pathogen at low levels is considered essential because most of the foods susceptible to contamination are ready-to-eat products, which are not cooked or otherwise processed before consumption. These considerations underline 
the benefit of monitoring sensitive L. monocytogenes to ensure the microbiological quality of foods and to reduce risks for public health.

The smoking, cooking, fermentation or drying processes used to make the samples tested can be considered effective antimicrobial processes for control of L. monocytogenes on RTE meals (Steven et al., 2006). The European community directive on milk and milk-based products specifies zero tolerance for soft cheese and the absence of the organism in $1 \mathrm{~g}$ of the product (Food Safety and Inspection Service, 2000).

Current microbiological culture methods rely on growth in culture media, followed by isolation, and biochemical and serological identification. However, the detection of this pathogen in food by these standard culture methods is made difficult by the sporadic or low levels of contamination $(<100 \mathrm{cfu} / \mathrm{g})$ can't be relied incase of the presence of a high level of background micro-flora and competitor organisms that could mask the presence of $L$. monocytogenes, or even interference due to food matrix components (Norton et al., 2001). Moreover, these methods are laborious and time consuming, requiring a minimum of five days to recognize Listeria spp. and about 10 days to identify L. monocytogenes by confirmatory tests (Anon, 1996), while immediate action should be taken in case of contamination since it is of fundamental importance to ensure the safety of food products, especially the case of those food matrices having short shelf-lives, such as meat or dairy products.

In the past years, advancements in biotechnology have resulted in the development of rapid methods that reduce analysis time and offer great sensitivity and specificity in the detection of pathogens. Among these, PCR has been increasingly used for the rapid, sensitive and specific detection of foodborne pathogens (Olsen et al., 1995). However, the successful application of PCR assays to food samples has been hindered by the lack of a rapid and efficient method for the preparation of PCR-amplifiable DNA (Lantz et al., 1994). The presence of PCR inhibitors in food samples (Rossen et al., 1992; Bickley et al., 1996) represented the main limitation in this kind of assays due to the production of false negative results. For this reason, the application of PCR-based methods is closely linked to the selection of suitable methods for DNA extraction.

The results obtained from isolation were in line with that of molecular diagnosis as PCR detected only the presence of L. monocytogenes in 4 basturma samples at $2^{\text {nd }}$ PCR. This clarify the 
reason why PCR didn't give any result at first time, but gave results with Re-PCR during the detection of $h y l$ and prfA genes.

Gouws and Liedemann (2005) and Amagliani et al. (2007) associated the main limitation with PCR application to foodcontaminating microorganisms concerns to the presence of inhibitory substances that are coextracted with DNA and may be present in the sample, causing a failure in the amplification reaction which leads to false negative results. Therefore, quality and purity of extracted nucleic acids are the main requirements for a PCR-based detection assay at the mean while the selection of a proper extraction method is determinant for a successful and valid PCR analysis.

This consideration could explain the results obtained for samples extracted using the boiling method suggested by Bansal et al. (1996), showing faint signals in gel analysis. Although lysis by boiling appeared to be the most convenient extraction protocol, particular care should be taken when food contamination with very low bacterial count is suspected. Cooray et al. (1994) noted that boiling for $5 \mathrm{~min}$ at $100^{\circ} \mathrm{C}$ was superior to heating at $95^{\circ} \mathrm{C}$ for releasing DNA from cells.

Oligonucleotide primers targeted to the L. monocytogenes hlyA gene were highly species specific and provide a means for easily differentiating L. monocytogenes from other hemolytic species of Listeria (Deneer and Boychuk, 1991). Several genes coding for various aspects of virulence in L. monocytogenes had been identified and used for PCR detection of the organism. Wernars et al. (1992) made use of the $\operatorname{prf} A$ gene to develop a highly specific PCR for recognition of pathogenic $L$. monocytogenes strains. The primers used, $\operatorname{prf} A-A / \operatorname{prf} A-B$, flank a 1060-bp sequence encompassing the entire prfA gene directed against nucleotides 181 to 207 and 1462-1482 of the prfA gene sequence, were found to be specific for all virulent strains of L. monocytogenes tested, and readily distinguished them from a-virulent strains of L. monocytogenes and representatives of the other six Listeria species (Levin, 2010).

In conclusion, this study has demonstrated the presence and distribution of $L$. monocytogenes in a variety of RTE meat products in Port-Said. PCR was more rapid and sensitive method, useful for the rapid detection of $L$. monocytogenes in a reasonable period of time which may avoid costly recalls and reducing outbreaks. As well as any ready-to-eat foods such as hot dogs, luncheon meats, cold cuts, fermented and dry sausage should be eaten only after they have been reheated to a high temperature. 


\section{REFERENCES}

Acciari, V.A.; Torresi, M.; Giacomo, G.; Elisabetta, S.; Prencipe, P. and Vincenza, P. (2011): Characterisation of Listeria monocytogenes strains isolated from soft and semi-soft cheeses sampled in a region of Italy. Vet. Ital., 47(1): 15-23, 5-13.

Amagliani, G.; Giammarini, C.; Omiccioli, E.; Brand, E. and Magnani, M. (2007): Detection of Listeria monocytogenes using a commercial PCR kit and different DNA extraction methods. Food Control, 18: 1137-1142.

Akpolat, N.O.; Elci, S.; Atmaca, S. and Gül, K. (2004): Listeria monocytogenes in products of Animal Origin in Turkey. Vet. Res. Commun., 28(7): 561-567.

Anon (1996): Rapporti ISTISAN ISSN 1123-3117, 96/35.

Anon (2003): FDA/Center for Food Safety and Applied Nutrition, USDA/Food Safety and Inspection Service, Centers for Disease Control and Prevention, Quantitative assessment of relative risk to public health from foodborne Listeria monocytogenes among selected categories of ready-to-eat foods, September 2003.

Azevedo, I.; Regalo, M.; Mena, C.; Almeida, G.; Carneiro, L.; Teixeira, P.; Hogg, T. and Gibbs, PA. (2005): Incidence of Listeria spp. in domestic refrigerators in Portugal. Food Control; 16(2): 121-124.

Aznar, R. and Alarcón, B. (2003): PCR detection of Listeria monocytogenes: a study of multiple factors affecting sensitivity. J. Appl. Microbiol., 95: 958-966.

Bansal, N.S.; McDonell, F.H.; Smith, A.; Arnold, G. and Ibrahim, G.F. (1996): Multiplex PCR assay for the routine detection of Listeria in food. International Journal of Food Microbiology, 33: 293-300.

Bansal, N.S. (1996): Development of a polymerase chain reaction assay for the detection of Listeria monocytogenes in foods. Letters of Applied Microbiology, 22: 353-6.

Bickley, J.; Short, J.K.; McDowell, D.G. and Parkes, H.C. (1996): Polymerase chain reaction (PCR) detection of Listeria monocytogenes in diluted milk and reversal of PCR inhibition caused by calcium ions. Letters in Applied Microbiology, 22: $153-158$. 
Borucki, M.K.; Peppin, J.D.; White, D.; Loge, F. and Call, D.R. (2003): Variation in biofilm formation among strains of Listeria monocytogenes. Appl. Environ. Microbiol., 69: 7336-7342.

Busani, L.; Cigliano, A. and Tailoli, E. (2005): Prevalence of Salmonella enterica and Listeria monocytogenes contamination in foods of animal origin in Italy. J. Food Prot., 68 (8): 1729-1733.

Cooray, K.J.; Nishibori, T.; Xiong, H.; Matsuyama, T.; Fujita, M. and Mitsuyama, M. (1994): Detection of multiple virulenceassociated genes of Listeria monocytogenes by PCR in artificially contaminated milk samples. Appl. Environ. Microbiol., 60: 3023.

Cressey, P. and Lake, R. (2005): Risk ranking: Estimates of the cost of food borne disease for New Zealand". ESR Client Report FW07102. Christchurch: ESR.

Cressey, $P$. and Lake, R. (2007): Risk ranking: estimates of the burden of food borne disease for New Zealand. ESR Client Report FW0724. Christchurch: ESR.

D'Agostino, M.; Wagner, M.; Vazquez-Boland, J.A.; Kuchta, T.; Karpiskova, R.; Hoorfar, J.; Novella, A.; Scortii, M.; Ellison, J.; Murray, A.; Fernandes, I.; Kuhn, M.; Pazlarova, J.; Heuvelink, A. and Cook, N. (2004): A validated PCR-based method to detect Listeria monocytogenes using raw milk as a food model - towards an International Standard. Journal of Food Protection, 67: 1646-1655.

Deneer, H.G. and Boychuk, I. (1991): Species-specific detection of Listeria monocytogenes by DNA amplification. Appl Environ Microbiol., 57(2): 606-609.

Elgazzar, M.M.M. and Sallam, Kh.I.A. (1997): Occurrence of Listeria monocytogenes and other listeria species in meat products. Alexandria Journal of Veterinary Science 13, 4: 415- 422.

El-prince, E. and Sayed, A.S.M. (2004): A survey on the presence of Listeria species in raw milk, Ice-cream and Human stool with characterization of some isolate by sds-page". Assiut Vet. Med. J., 50(101): 94-109.

FDA, (2003): BAM, Detection and Enumeration of $L$.monocytogenes. $8^{\text {th }}$ Ed. Revision A, 1998, Chapter 10, Author: Antony D. Hitchins.

Fraser, J. and Sperber, W. (1988): Rapid detection of Listeria in food and environmental samples by esculin hydrolysis. J. Food Prot., 51: 762-765. 
Food Safety and Inspection Service "FSIS" (2000): FSIS Action Plane for Addressing Listeria monocytogenes. United States Department of Agriculture, Washington, D.C. 20250-3700.

Gill, C.; Bryant, J. and Badoni, M. (2001): Effect of hot water pasteurizing treatments on the microbiological condition of manufacturing beef used for hamburger patty manufacture. J. Food Micro., 63: 243-256.

Glass, K.A. and Doyle, M.P. (1989): Fate and thermal inactivation of Listeria monocytogenes in processed meat products during refrigerated storage. Appl. Environ. Microbiol., 55:1565-1569.

Gouws, P.A. and liedemann, I. (2005): Evaluation of diagnostic PCR for the detection of Listeria monocytogenes in food products. Food Technol. Biotechnol., 43: 201-205.

Griffiths, M.W. (1989): Listeria monocytogenes: its importance in the dairy industry. Journal of the Science of Food and Agriculture, 47: 133-158.

Hamedy, H.E.; Ashraf, M.A. and Eman, E.A.S. (2007): Determination of some heavy metals in some ready to eat meals in Assiut city. Assiut Vet. Med., 53(113):111-123.

Hege, K.N.; Knut, R.; Kristine, N.; Askild, H. and Dag, L. (2000): Application of 5'-Nuclease PCR for Quantitative Detection of Listeria monocytogenes in Pure Cultures, Water, Skim Milk, and Unpasteurized Whole Milk. Applied and Environmental Microbiology, 66(10): 4266-4271.

Janny, M.A. (2007): Listeria monocytogenes in food". Food Safety Focus, 8 th issue, March- incident in focus.

Janzten, M.M.; Navas, J.; Corujo, A.; Moreno, R.; Lopez, V. and Martinez-Suarez, J.V. (2006): Review. Specific detection of Listeria monocytogenes in foods using commercial methods: from chromogenic media to real-time PCR. Span. J. Agric. Res., 4: 235-247.

Jung, H.J.; Park, S.; Ha, S.; Lee, K.; Chung, D.; Kim, C.; Kim, M.; Kim, K.; Kim, K. (2009): Species-specific detection of Listeria monocytogenes using polymerase chain reaction assays targeting the $\operatorname{prfA}$ virulence gene cluster. Biosci Biotechnol. Biochem.,73 (6): 1412-5.

Lantz, P.G.; Hahn Hagcrdal, B. and Radstrom, P. (1994): Sample preparation methods in PCR-based detection of food pathogens. Trends in Food Science and Technology, 5: 384-389. 
Levin, R.E. (2003): Application of the polymerase chain reaction for detection of Listeria monocytogenes in foods: a review of methodology. Food Biotechnol., 17: 99-116.

Levin, E.R. (2010): Rapid Detection and Characterization of Foodborne Pathogens by Molecular Techniques. Chapter 12. Listeria monocytogenes. CRC Press: 411-455.

Mohamed, Amal, A. and Ali, M.M. (1999): Incidence of Listeria monocytogenes in some meat products and poultry. Assiut Vet. Med. J. 40(80): 581-584.

Mugampoza, D.; Muyanja, C.M.B.K.; Ogwok, P.; Serunjogi, M.L. and Nasinyama, G.W. (2011): Occurrence of Listeria monocytogenes in bulked raw milk and traditionally fermented dairy products in Uganda. African Journal of Food, Agriculture, Nutrition and Development, 11 (2): 4610- 4622.

Norton, D.M.; McCamey, M.A.; Gall, K.L.; Scarlett, J.M.; Boor, K.J. and Wiedmann, M. (2001): Molecular studies on the ecology of Listeria monocytogenes in the smoked fish processing industry. Applied and Environmental Microbiology, 67(1): 198-205.

Olsen, J.E.; Aabo, S.; Hill, W.; Notermans, S.; Wernars, K. and Granum, P.E. (1995): Probes and polymerase chain reaction for detection of food-borne bacterial pathogens. International Journal of Food Microbiology, 28: 1-78.

Rossen, L.; Norskov, P.; Holmstrom, K. and Rasmussen, O.F. (1992): Inhibition of PCR by components of food samples, microbial diagnostic assays and DNA extraction solutions. International Journal of Food Microbiology, 17: 37-45

Saad, M.S. (2001): Prevalence of listeria species in meat in meat and meat products. Vet. Med. J., Giza. 49, 4: Turkey. Food Microbiology, 22: 543-552.

Steven, C. Ingham; Gina Searls and Dennis, R. Buege (2006): inhibition of Salmonella serovars, Escherichia coli O157:h7 and Listeria monocytogenes during dry-curing and drying of meat: a case study with basturma". Journal of Food Safety, 26: 160-172.

Sue, G.; Rob, L.; Andrew, H. and Peter, C. (2009): Risk profiles: Listeria monocytogenes in ready to eat meats. ESR Client Report FW08021. Christchurch: ESR.

Sutherland, P.S.; Miles, D.W. and Laboyrie, D.A. (2003): Listeria monocytogenes. In: Hocking AD (eds). Food borne Microorganisms of Public Health Significance. Sixth edition. 
Sydney: Australian Institute of Food Science and Technology Inc.

The American Meat Institute Foundation (2005): Instructions for using the AMI process lethality determination spreadsheet". http://www.amif.org/FactsandFigures/AMIF-Process- Process Lethality . htm \#instructions (accessed October 12, 2005).

Tompkin, R.B.; Christiansen, L.N.; Shaparis, A.B.; Baker, R.L and Schroeder, J.M. (1992): Control of Listeria monocytogenes in processed meats. Food. Australia, 44: 370-376.

USDA (2004): Control of Listeria monocytogenes in Ready-to-Eat Meat and Poultry Products. Fed. Register 68: 34207-34254.

Uyttendaele, M. (1997): Incidence of Listeria monocytogenes in poultry and poultry products obtained from Belgian and French abattoirs. Food Microbiol; 14: 339-345.

Vorst, K.L.; Todd, E.C. and Rysert, E.T. (2006): Transfer of Listeria monocytogenes during mechanical slicing of turkey breast, bologna, and salami. Journal of Food Protection, 69(3): 619-626.

Wernars, K.; Heuvelman, K.; Notermans, S.; Domann, E. and Leimester-Wachter, M. (1992): Suitability of the prfA gene, which encondes a regulatory of virulence genes in Listeria monocytogenes in the identification of pathogenic Listeria spp. Appl. Environ. Microbiol., 58: 765-768.

William, R.H. and Catherine, C. (2001): Controlling Listeria monocytogenes in small and very small meat and poultry plants United States Department of Agriculture food Safety Inspection Service Washington, D.C. 20250-3700.

Wong, A.C. (1998): Biofilms in food processing environments. J. Dairy Sci., 81: 2765-2770. 